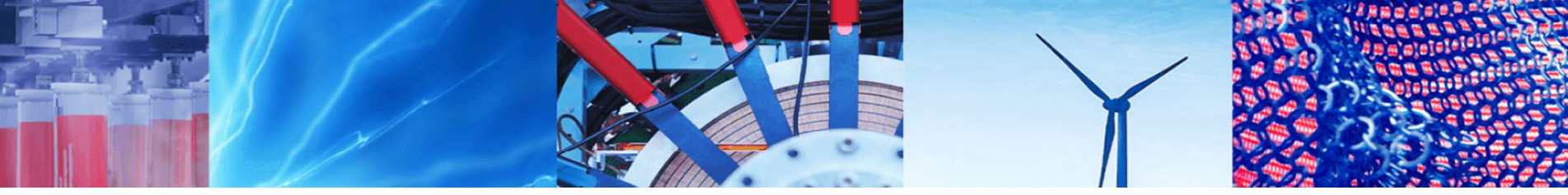

Review Paper

\title{
Comparative study of heat storage and transfer system for solar cooking
}

\author{
Tharesh K. Gawande ${ }^{1}$. D. S. Ingole ${ }^{1}$
}

Received: 9 September 2019 / Accepted: 21 November 2019 / Published online: 25 November 2019

(c) Springer Nature Switzerland AG 2019

\begin{abstract}
To run the Solar energy appliances, the continuous availability of solar energy is an essential. The Solar appliances are run by using solar energy either from PV cell or solar collector. Both of these devices require continuous solar rays. In order to use the solar energy after sunshine, it requires being stored first and then can be transferred to the appliances. One of the focused applications by using solar energy is the solar cooking. A Lot of research is going on the use of solar energy for cooking. But still, some extensive technique needs develop for easily usable systems. The various solar cookers are discussed to insist the need for development of solar storage systems for efficient cooking. This paper presents the comparative study of heat storage and transfer systems for solar cooking. The key aspects like, methodology to develop the heat storage system, requirements and properties of heat storage materials, need of insulations and their types are addressed. Some most usable materials are also analyzed.
\end{abstract}

Keywords Heat storage system · PCM · Solar cooking

\begin{tabular}{ll}
\multicolumn{2}{l}{ List of symbols } \\
$\mathrm{PCM}$ & Phase change material \\
$\mathrm{HTF}$ & Heat transfer fluid \\
$\mathrm{x}$ & Fraction melted \\
$\mathrm{Cp}$ & Specific heat $(\mathrm{kJ} / \mathrm{kg} \mathrm{K})$ \\
$\mathrm{Csp}$ & $\begin{array}{l}\text { Average specific heat between } \mathrm{T} 1 \text { and } \mathrm{Tm}(\mathrm{kJ} / \\
\\
\mathrm{kg} \mathrm{K})\end{array}$ \\
$\mathrm{Clp}$ & $\begin{array}{l}\text { Average specific heat between } \mathrm{Tm} \text { and } \mathrm{T}_{2}(\mathrm{~kJ} / \\
\end{array}$ \\
$\mathrm{kg} \mathrm{K})$ \\
$\mathrm{dt}$ & Change in temperature in ${ }^{\circ} \mathrm{C}$ \\
$\mathrm{m}$ & Mass of heat storage medium $(\mathrm{kg})$ \\
$\mathrm{Q}$ & Quantity of heat stored $(\mathrm{kJ})$ \\
$\mathrm{T}_{2}$ & Final temperature $\left({ }^{\circ} \mathrm{C}\right)$ \\
$\mathrm{T}_{1}$ & Initial temperature $\left({ }^{\circ} \mathrm{C}\right)$ \\
$\mathrm{Tm}$ & Melting temperature $\left({ }^{\circ} \mathrm{C}\right)$ \\
$\mathrm{hm}$ & Heat of fusion per unit mass $(\mathrm{kJ} / \mathrm{kg})$ \\
$\mathrm{VSI}$ & Vacuum super insulation \\
$\mathrm{VIM}$ & Vacuum insulation material
\end{tabular}

VIP Vacuum insulation panel

NIM Nano insulation material

\section{Introduction}

Solar cookers are the means to cook food with the help of solar energy. For this purpose, the solar energy can be collected using solar collector and transferred to the cooking vessel. The solar cooking is in practice since seventeenth century with continuous research efforts to improve the performance of cooker. The solar cooking was started with the solar cooker box and has been developed into various forms in due course of time. But, in the present condition the solar cookers are rarely used. Its main reason limits the usefulness of solar cookers in sunshine time only. The cooking at night or in cloudy days is not possible. This has created a necessity for development of solar cookers which can work at night as well as in cloudy days.

Tharesh K. Gawande, tharesh01@gmail.com; D. S. Ingole, dsingole@rediffmail.com | 'Department of Mechanical Engineering, PRMIT\&R, Badnera, Amravati, India. 
As the energy demand is increasing day by day with increasing population and pollution, the need of renewable energy is becoming the very essential in every field. There are various sources for renewal energy which are being widely used now days. Solar energy is the one of a very popular and easily available source of renewable energy. Still its use is only about $4 \%$ of total renewable energy used [1]. This solar energy can be used by means of photovoltaic (PV) cell or solar collectors. It has several uses like drying, space heating, cooking, electricity generations etc. [2-5]. And one of the well-known uses of solar energy is to cook the food [6]. It requires proper mechanism to use this solar energy for solar cooking. And it is done with the help of solar cookers. Till now, lot of solar cookers have been designed and used. It is being developed since seventeenth century [7-9]. Still it needs lot of research before selecting any one type for its use at specific region. It depends on geographical area, type of collector \& its area, heat requirement, type of food to be cooked; at what time it is to be cooked etc. [10]. Among all those different designs, a simple solar box type cooker is used commonly due to its simplicity. The use of a solar box cooker is limited because cooking of food is difficult due to frequent clouds in the day or unavailability of solar energy in the evening. So cooking at night by this solar box cannot be done. Some have used hybrid energy also to improve the efficiency of cooker [11]. If storage for solar energy can be provided in a box cooker, then there is a possibility of cooking food in the evening and this will increase the effectiveness and reliability of these solar cookers [12-14]. This leads to need of indoor cooking system $[15,16]$. For a solar cooking system to be accepted and adopted in most of the households, the following characteristics have to be satisfied [17-20]:

1. Possibility of cooking at any time of day

2. Cooking time must be comparable with conventional cooking

3. Economical aspect

To overcome above cited limitations and gain the desirable characteristics, researchers reported their findings $[15,21]$. There are different heat storage systems (Heat Exchangers) available in the market. So, exact selection of most suitable becomes very difficult. Most of the time it become necessary to design and develop customized system which can meet the purpose. The solar collectors are classified as follows [22, 23]: a. Stationary Collectors

(i) Flat plate collectors

(ii) Evacuated tube solar collectors

(iii) Com-

pound

parabolic

collectors

b Single axis tracking collectors

(i) Linear Fresnel reflectors

(ii) Parabolic trough col-

(iii) Cylindrical collectors

c. Two-axes tracking collectors

$\begin{array}{ll}\text { (i) Parabolic dish reflec- } & \text { (ii) Heliostat field collec- }\end{array}$ tors tors

According to Soteris A. Kalogirou [23], the temperature up to $400^{\circ}$ can be obtained by using parabolic trough collector and even more than that is also possible by using parabolic dish reflector. So, taking this as a reference one can select the suitable solar collector. Hence, in such types of systems, energy storage and transportation is the key work. Solar energy has to be transported to the kitchen by means of a circulating fluid. Therefore, the critical study of heat storage and transfer systems along with their parameters attracts the attention of researchers.

\section{Heat storage systems}

Heat collected from the sun is used for the solar cooking but if it is directly supplied to cooking then it will be useful in day time/sunshine hours only. To carry the cooking at any time, one needs to store this heat so that it can be retrieved as and when required [24]. To store this heat the storage system is required which will be able to store the heat with minimum losses, so as to store the heat at least in the range of $200-300{ }^{\circ} \mathrm{C}$ [25]. Therefore, for the efficient heat storage systems following parameters must be considered:

i. Type of solar cooking system (heat exchanger)

ii. Heat storage capacity

iii. Size and volume of the storage system

iv. Heat losses and insulation

v. Heat storing Media

vi. Temperature range

vii. Application (direct use or use for steaming) $[26,27]$

\subsection{Type of solar cookers with storage}

Solar cookers are available in various forms. Its design resembles to the design of heat exchangers which are too 


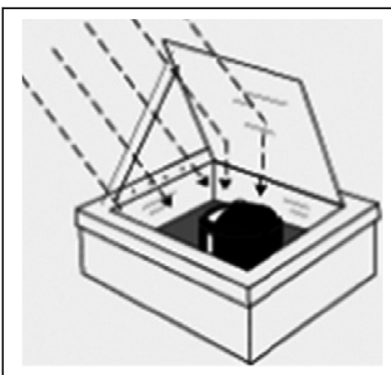

i) Box Cooker

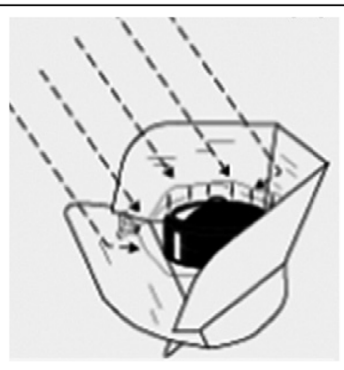

ii.) Solar Panel Cooker

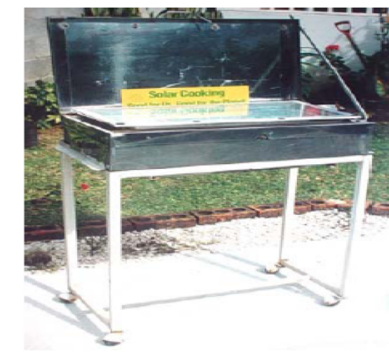

iii.) Simple Solar Box oven

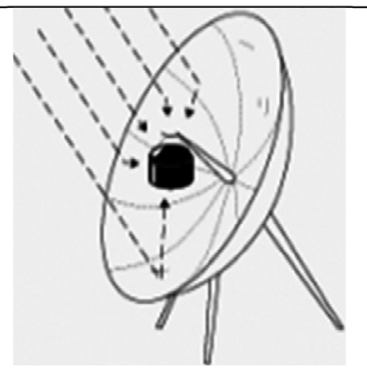

iv.) Parabolic Cooker

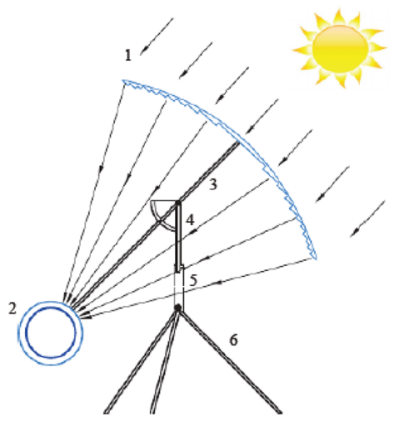

v.) Fresenel lens concentrator cooker
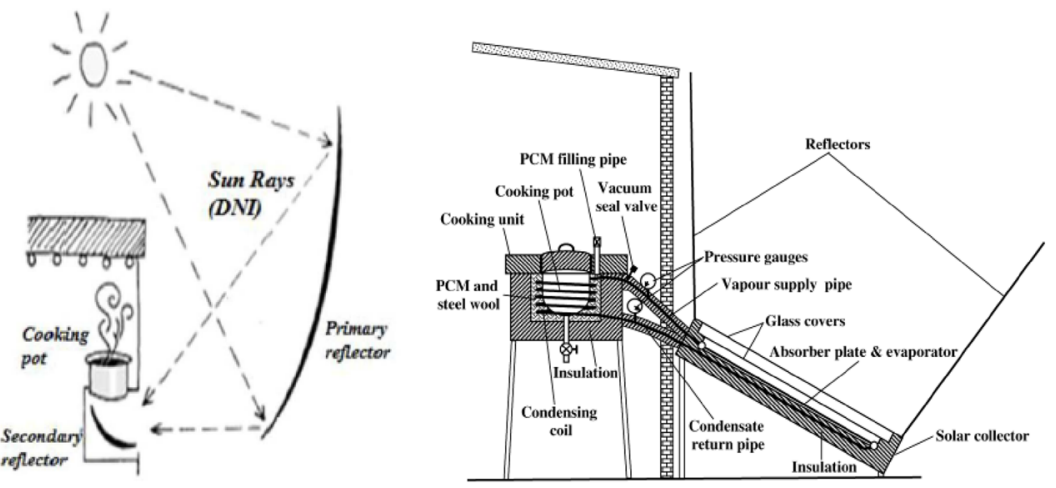

vi.) Scheffler dish Cooker

vii.)Solar Cooker with PCM

Fig. 1 Different Types of Solar Cookers

much depended on the geometry and its type $[28,29]$. Mostly direct box type heat exchanges are used for solar box cooker while shell and tube can be used for the storage systems [30]. Solar Cookers can be classified as below: [8, 31-35] (Fig. 1)

\begin{tabular}{|c|c|c|}
\hline i. Solar box cooker & ii. Solar panel cooker & $\begin{array}{l}\text { iii. Simple hot box } \\
\text { oven }\end{array}$ \\
\hline $\begin{array}{l}\text { iv. Solar parabolic } \\
\text { cooker }\end{array}$ & $\begin{array}{l}\text { v. Fresnel lens Con- } \\
\text { centrator cooker }\end{array}$ & vi. Scheffler dish \\
\hline $\begin{array}{l}\text { vii. Solar cooker wit } \\
\text { PCM }\end{array}$ & & \\
\hline
\end{tabular}

There are so many box types of solar cookers available which work in day time only. Its evaluation is done by some researchers [36, 37]. Some other researchers worked on solar cookers with storage systems. And some of them used the conventional box cooker and to which heat storage system is attached. Out of those, double glazed box with PCM was good initiative to cook the food after $5 \mathrm{pm}$ also [38]. But according to the author, it didn't give the sufficient temperature to cook food only on storage system. General observations made by some researchers are shown in Table 1.

Prima facie it observes that food can be cooked in large scale with minimum time in outdoor cooker when storage is utilized. This fact helps in developing the new system (rather than box type only) with storage which can be used in the absence of light. For this, design and material selection for storage systems are the key factors.

\subsection{Heat storage capacity}

While designing the heat storage system, its heat storage capacity is very important parameter to decide. It depends on the application (in this case cooking) [43]. The requirement of heat depends upon the type of food to be cooked and the number of persons for whom food is to be cooked. The designed storage system should be able to meet the requirements of cooking for stated number of persons. For sensible heat storage, the capacity of storage system can be calculated by using following general relationship [44, 45]: 
Table 1 Comparative solar cooker performance of PCM box cooker

\begin{tabular}{|c|c|c|c|c|c|}
\hline Sr. no. & Parameter/researcher & Buddhi [39] & Sharma [40] & Schwarzer [41] & Gedam [42] \\
\hline 1 & Type of storage & $\begin{array}{l}\text { Double glazed (glass } \\
\text { covers) box with PCM }\end{array}$ & $\begin{array}{l}\text { PCM cooker (Box } \\
\text { type with glass) }\end{array}$ & $\begin{array}{l}\text { Outdoor solar } \\
\text { cooker with } \\
\text { storage }\end{array}$ & $\begin{array}{l}\text { double glazed (glass cov- } \\
\text { ers) box with PCM }\end{array}$ \\
\hline 2 & Size & $50 \times 50 \mathrm{~cm} \times 19 \mathrm{~cm}$ deep & Dia25 cm $\times 8 \mathrm{~cm}$ & $4 \mathrm{~m}^{2}$ & 0.1344 sq. $\mathrm{m}$ aperture area \\
\hline 3 & Material used & Acetanilide & Acetanilide & & Paraffin \\
\hline 4 & Food cooked kg & 0.5 & 0.3 & $20 \mathrm{~kg}$ oil & Water \\
\hline 5 & Maximum temperature $\left({ }^{\circ} \mathrm{C}\right)$ of $\mathrm{PCM}$ & 137.5 & 119.5 & 235 & - \\
\hline 6 & Maximum Temperature $\left({ }^{\circ} \mathrm{C}\right)$ of food & 94.5 & 101.6 & - & 95 \\
\hline 7 & On PCM only $\left({ }^{\circ} \mathrm{C}\right)$ & 80 & - & - & - \\
\hline 8 & Time for cooking in minutes & 120 & 120 & 37 & 90 \\
\hline
\end{tabular}

$\Delta h=m \cdot C p d t$

where $\mathrm{m}$ is the mass of sensible heat storing material, $C p$ specific heat of material, $d t$ is change in its temperature.

Whereas for the latent heat storage system, heat stored by the system can be calculated as [46]:

$$
\begin{aligned}
Q & =\int_{T 1}^{T m} m \cdot C p d t+m \cdot \Delta h_{m}+\int_{T 1}^{T m} m \cdot C p d t \\
& =m\left[\operatorname{Cps}\left(T m-T_{1}\right)+\Delta h_{m}+C p l\left(T_{2}-T m\right)\right]
\end{aligned}
$$

i.e. $Q=$ sensible heat in solid state of $P C M+$ latent heat of fusion + sensible heat of PCM in liquid state.

So using above relations, one can find out the capacity of the system as well as can design the system.

\subsection{Size and volume of the storage system}

For the solar cooking to be easily adoptive by all the households, it should be easily portable. Hence size and volume of the system should be smaller which is better for short payback periods [47]. For this, the higher density material is preferred. While designing the system, it can be designed according to heat storage requirement or volume of the storage system. The performance of the system can be evaluated on the basis of heat supplied that is cooking power supplied for the number of people [48]. So it becomes difficult to design the system accordingly by calculating the heat required and converting it into volumes. Hence it is preferred to design it volume wise. And then it can be develop for the heat requirement.

\subsection{Heat losses and insulation}

For solar cooking at any time, the heat storage unit is an essential mean as we want to store the heat so as to use it at required time. Heat storing doesn't solve the whole purpose as stored heat should not be dissipated. This heat dissipation may occur due to various heat losses [49]. Therefore to prevent these heat losses, a proper insulation is required [8]. Some insulating material like the mineral wool (stone wool), Polystyrene, aerogel, Vacuum super insulation (VSI), vacuum insulation material (VIM), Glass ceramic foam, vacuum insulation panel VIP and Nano insulation material NIM can be used. Properties of the some insulating materials are given in following Table 2 [50-52]

Depending on the operating range, size and volume, the insulation material should to be selected.

\subsection{Heat storing media}

Depending on the media, basically there are two types of heat (thermal) storage systems [53-55]

i. Sensible heat storage system and ii. Latent heat storage system

Table 2 Insulating materials \& its properties

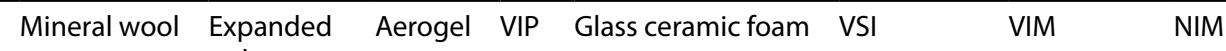
polystyrene

\begin{tabular}{lllllllll}
\hline Thermal conductivity $\mathrm{mW} /(\mathrm{m} \mathrm{K})$ & $30-40$ & $30-40$ & $13-14$ & $3-4$ & 360 & $8-20$ & $<4$ & $<4$ \\
Site adaption/cutting & Yes & Yes & Yes & No & May be & No & Yes & Yes \\
Load bearing capacity & No & No & No & No & Yes/may be & Yes/may be & No/may be & No/may be \\
\hline
\end{tabular}




\subsubsection{Sensible heat storage}

Specific heat capacity of the material is utilized to store the thermal energy in sensible heat storage [56]. An effectiveness of the storage depends on the store material. The material should have following characteristics [57-59]:

i. long service life, non-corrosive, non-toxic, non-flammable - large heat storage capacity

ii. high thermal diffusivity $a=k / \rho c p$ in $\mathrm{m}^{2} / \mathrm{s}$ and heat diffusivity $b=\mathrm{k} . \rho, \mathrm{cp}$ in $\mathrm{kJ} / \mathrm{kgK}$; with $k$ being the thermal conductivity, $\rho$ the density and $c p$ the specific heat capacity

iii. capability to withstand charging/discharging cycles without loss in performance, store capacity or change in structure [60]

iv. wide availability, simple handling, storage in simple containers

v. low cost

\subsubsection{Latent Heat storage System}

Storing and retrieving the thermal energy is based on the latent heat of fusion of the material. Where storage medium undergoes a phase transformation which can be either solid to liquid or liquid to gas is latent heat storage system. It uses phase change material to store the heat which can retrieve the energy when outside temperature will be less. These phase change material (PCM) possesses some thermal, physical \& chemical properties. Like suitable phase-transition temperature, high latent heat of transition, good heat transfer, favorable phase equilibrium, high density, small volume change, low vapor pressure, longterm chemical stability, compatibility with materials of construction, no toxicity, no fire hazard etc. [46, 57]. Latent heat storage has more capacity and ability to retrieve the heat hence it is an area of research since last few years.

\section{Heat transfer system}

After the heat is gained from the sun by using solar collector, it can be stored in heat storage system. This heat transportation in and out of the system is very important [61]. But here the main difficulty can be observed in transferring heat from solar collector to heat storage and heat storage to actual cooking area. Actual heat transfer is taken as shown in below Fig. 2:

Heat from solar collector can be transferred to heat storage system with gravity effect. But to circulate the fluid from storage tank to cooker and cooker to tank again or to collector it requires external force that is pump. Dependending upon the circuilating fluid pump may be used [62]. Also selection of pump depends on the flow rate of fluid. Generally gear pump is used for the circulation of fluid as shown in Fig. 3. This pump may be DC pump or AC pump depends upon the drive given. Also Bourdon Pressure guage is used to monitor the pressure in the system as shown in Fig. 3. The another important factor is heat loses occurred during heat transfer. This can be minimised by using proper insulation on the pipes [63]. The insulation which can be used is presented in Table 2 .

\section{Material selections}

Material selection is also one of the main aspect in the development of Solar cooking system.

Material selection should be done for the following component of the system:
i. Material for shell \& Tubes (Heat Exchangers)
ii. Heat transfer fluid (HTF)
iii. Material for Storage (PCM)
iv. Material for Heat transfer system

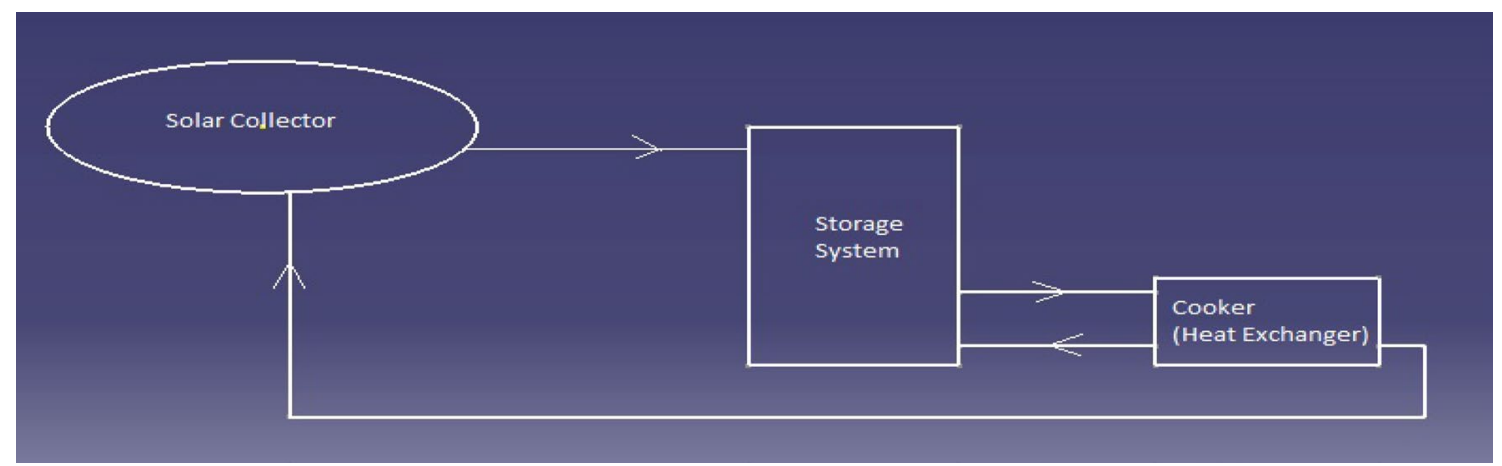

Fig. 2 Generalized Heat transfer System for Solar cooking with PCM 
Fig. 3 a Ciculating Pump, b bourdon tube pressure gauge

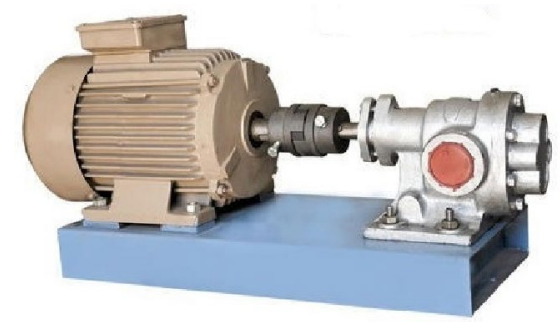

(a) Ciculating Pump

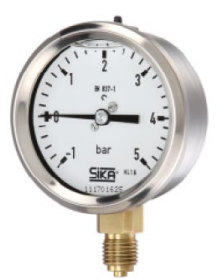

(b) Bourdon Tube Pressure Gauge
Table 3 Material with their thermal conductivity

\begin{tabular}{lllll}
\hline Material & \multicolumn{4}{l}{ Thermal conductivity $\mathrm{W} / \mathrm{mK}$} \\
\cline { 2 - 5 } & At $20{ }^{\circ} \mathrm{C}$ & $100^{\circ} \mathrm{C}$ & $200^{\circ} \mathrm{C}$ & $300^{\circ} \mathrm{C}$ \\
\hline Aluminum & 204 & 206 & 215 & 228 \\
Brass & 111 & 128 & 144 & 147 \\
Copper & 386 & 379 & 374 & 369 \\
Cast Iron & 52 & - & - & - \\
Carbon steel & 54 & 52 & 48 & 45 \\
Silver & 419 & 415 & 412 & - \\
\hline
\end{tabular}

\subsection{Material for Heat Exchanger}

Heat storage \& cooking systems are obviously the heat exchangers. Hence its main function is to transfer the heat from one media to another. So it is always preferable to use material having higher thermal conductivity. Some materials along with their properties are given in Table 3 [64]. Generally tubes may be made up of copper and shell from the still sheets. [65]

\subsection{Heat transfer fluid}

Heat has to be transferred from solar collector to heat storage system to cookers and then back to collector. This fluid should have the $[27,66-70]$ following properties:

\begin{tabular}{lll}
\hline i. Good stability, & $\begin{array}{l}\text { ii. Low vapor pres- } \\
\text { sure, }\end{array}$ & \\
iii. Low freeze point, & iv. Low viscosity & $\begin{array}{l}\text { v. Higher mass flow } \\
\text { rate }\end{array}$ \\
\end{tabular}

Corrosiveness is also one of the important factors to be considered while selecting the fluid.

\subsection{Material for Storage (PCM)}

For latent heat storage system, selection of phase change material is very crucial.

SN Applied Sciences
Phase change material can be classified as below:-

i. Organic- Paraffin \& Non Paraffin (fatty acids)

ii. Non organic-Salt hydrates and metallic

iii. Eutectics-it's a mixture of two or more component [71]

There are lots of PCM available now days but its selection is very crucial thing [72]. It depends on the availability and applicability of the PCM of the selected purpose. Some of the promising PCM are mentioned in the below Table 4.

The paraffins are safe, reliable, predictable, less expensive and non-corrosive. They are chemically inert and stable below $500^{\circ} \mathrm{C}$, show little volume changes on melting and have low vapor pressure in the melt form. Salt hydrates are the most important group of PCMs, which have been extensively studied for their use in latent heat thermal energy storage systems. The most attractive properties of salt hydrates are: (i) high latent heat of fusion per unit volume, (ii) relatively high thermal conductivity and (iii) small volume changes on melting. They are not very corrosive, compatible with plastics. This makes $\mathrm{NaOH}$ $\mathrm{H}_{2} \mathrm{O}$ and $\mathrm{NaNO} 3$ promising $\mathrm{PCM}$ for the required range of melting temperature. Sugar alcohols (D- Manitol, Myoinositol, Dulcitol, Erythritol and Sorbitol) are suitable PCM for medium temperature applications. The bases of the selection criterion are mainly on two points: (1) high phase change enthalpy and (2) melting temperatures between 150 and $250^{\circ} \mathrm{C}$. Also, HDPE is non-hazardous and economical, hence it can be used as a PCM.

\section{Research limitations \& implications}

This paper is mainly focused on the application of solar energy for solar cooking. The solar collector is very important and can change the total cost evaluation and may affect complete economical aspect. Hence, the study and evaluation of solar collector can be carried out separately. From the literature survey and study of 
Table 4 Some Suitable PCM with melting temp \& Latent Heat values

\begin{tabular}{llll}
\hline Material & Melting temp ${ }^{\circ} \mathrm{C}$ & $\begin{array}{l}\text { Enthalpy (Latent Heat) of } \\
\text { Fusion kJ/kg }\end{array}$ & Reference/Researcher \\
\hline D-mannitol & 138.25 & 152.60 & {$[73]$} \\
Myo-inositol & 220.34 & 211.10 & {$[73]$} \\
Dulcitol & 180.07 & 257.15 & {$[73]$} \\
Parafin Wax 6106 & $42-45$ & 189 & {$[44,74,75]$} \\
Erythritol & 120 & 340 & {$[53,76,77]$} \\
High density polyethylene & 130 & $211-233$ & {$[78]$} \\
$\quad$ (HDPE) & & & {$[79,80]$} \\
Sorbitol & 97 & 185 & {$[57,81]$} \\
$\mathrm{NaNO}_{3}$ & 307 & 172 & {$[44]$} \\
$\mathrm{NaOH}^{-\mathrm{H}_{2} \mathrm{O}}$ & 64.3 & 273 & {$[57]$} \\
$\mathrm{KNO}_{3}-\mathrm{NaNO}_{2}-\mathrm{NaNO}_{3}$ & 141 & 275 & \\
\hline
\end{tabular}

the various aspects, a methodology has been proposed which may be useful for designing and developing new system possibly suitable for all time. This proposed system is a latent heat storage system for solar cooking which seems to be more efficient and economical. The proposed methodology is as shown below:
Hence, the system which can easily store the heat and transport it to cooking vessel as per requirement has to be developed by considering all the factors discussed till now.

Latent Heat Storage System for Solar Cooking

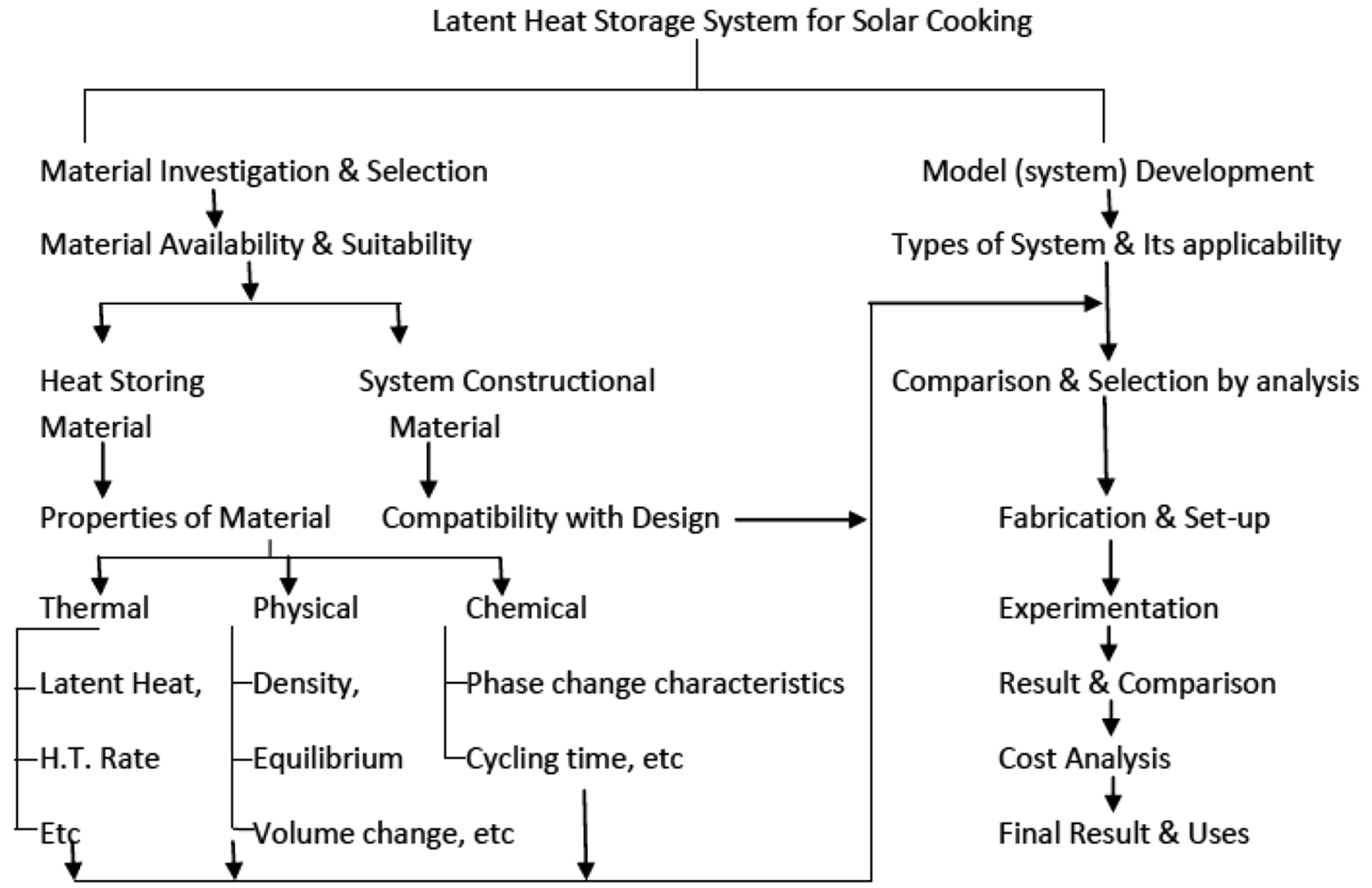




\section{Conclusion}

For the development of efficient solar cooker, heat storage is very essential and in turn the heat transfer system also becomes necessary. With more reliability, economy and efficiency, latent heat storage system can be the most suitable system for solar cooking. Depending on the suitability and applicability one can select the better method as discussed in this paper. The proposed latent heat storage system has been presented. The material selection and designing of the system are identified as the prominent factors for development of heat storage and transportation system. In this system, PCM to be used for which, Paraffin Wax, Myo-inositol, $\mathrm{HDPE}, \mathrm{NaOH}-\mathrm{H}_{2} \mathrm{O}$ and $\mathrm{KNO}_{3}-\mathrm{NaNO}_{2}-\mathrm{NaNO}_{2}$ materials looks more promising. But its easily availability in market is one of the concern. If this goes on larger scale then these materials can be of better use and can have better systems. Development of highly efficient and economical system can take place the occupancy in every kitchen which can save lot of conventional fuels which in turn will save the lot of economy of country. Further development and experimentation is needed to prove these concepts.

\section{Compliance with ethical standards}

Conflict of interest On behalf of all authors, the corresponding author states that there is no conflict of interest.

\section{References}

1. Kale DM (2012) Non-conventional energy sources: current scenario and future trends, a key-note address. In: 9th Biennial international conference and exposition on petroleum geophysics, Hyderabad

2. Nandwani SS (2007) Design, construction and study of a hybrid solar food processor in the climate of Costa Rica. Renew Energy 32:427-441

3. Hajian M (2013) Various aspects of solar energy utilization: review. Int J Adv Sci Technol 58:41-50

4. Singh M, Sethi VP (2018) On the design, modelling and analysis of multi-shelf inclined solar cooker-cum-dryer. Sol Energy 162:620-636

5. Jaluria Y (1989) Design, optimization and control of a thermal energy storage system. Energy storage systems. Kluwer Academic Publishers, pp 89-116

6. Yettou F, Azoui B, Malek A, Gama A, Panwar NL (2014) Solar cooker realizations in actual use: an overview. Renew Sustain Energy Rev 37:288-306

7. Mahavar S, Sengar N, Rajawat P, Verma M, Dashora P (2012) Design development and performance studies of a novel Single Family Solar. Renew Energy 47:67-76

8. Cuce E, Cuce PM (2013) A comprehensive review on solar cookers. Appl Energy 102:1399-1421
9. Saxena A, Pandey SP, Srivastav G (2011) A thermodynamic review on solar box type cookers. Renew Sustain Energy Rev 15:3301-3318

10. Avilés G, Juan J (2014) Thermal model of a solar cooker jorhejpataranskua. Energy Procedia 57:1623-1631

11. Azam M, Jamil Y, Musadiq M, Zhaira R, Yasir Javed M (2009) Fabrication and performance study of slope type electric cum solar oven. Pak J Agric Sci 46(3):228-231

12. Otte PP (2014) Solar cooking in Mozambique-an investigation of end- user's needs for the design of solar cookers. Energy Policy 74:366-375

13. Dheep GR (2014) Latent heat storage system for solar thermal energy applications. Voice of Research 2(4):80-86

14. Muthusivagami RM, Velraj R, Sethumadhavan R (2010) Solar cookers with and without thermal storage-a review. Renew Sustain Energy Rev 14:691-701

15. Prasanna LUUR (2011) Modeling and design of a solar thermal system for hybrid cooking application. Appl Energy 88:1740-1755

16. Abdulateef AM, Abdulateef J, Mat S, Sopian K, Elhub B, Mussa MA (2018) Experimental and numerical study of solidifying phase-chang Experimental and numerical study of solidifying phase-change material in a triplex-tube heat exchanger with longitudinal/triangular fins. Int Commun Heat Mass Transfer 90:73-84

17. Sosa LBL, Avilés MG, Pérez DG, Gutiérrez YS (2014) Rural Solar Cookers, an alternative to reduce the timber resource extraction through the use of renewable energy sources: technology transfer and monitoring project. Energy Procedia 57:1593-1602

18. Prasanna LUUR (2011) Optimization and design of energy transport system for solar cooking application. Appl Energy 88:242-251

19. Bansal M, Saini RP, Khatod DK (2013) Development of cooking sector in rural areas in India-a review. Renew Sustain Energy Rev 17:44-53

20. Zhao J, Ji Y, Yuan Y, Zhang Z, Lu J (2018) Energy-saving analysis of solar heating system with PCM storage tank. Energies 11:1-19

21. Hussein HE-GSNHMS (2008) Experimental investigation of novel indirect solar cooker with indoor PCM thermal storage and cooking unit. Energy Convers Manag 49:2237-2246

22. Hossain RSHFNRMIJAMRMS (2011) Review on solar water heater collector and thermal energy performance of circulating pipe. Renew Sustain Energy Rev 15:3801-3912

23. Kalogirou SA (2004) Solar thermal collectors and applications. Prog Energy Combust Sci 30:231-295

24. Kumar N, Budhiraja A, Rohilla S (2016) Feasibility of a solar cooker in off sunshine hours using pcm as the source of heat. Adv Eng Int J 1(1):33-39

25. Sulaiman FSA (2011) Development of a thermal energy storage for the integrated solar energy project. R\&D J South Afric Inst Mech Eng, pp 6-11

26. Indora S, Kandpal TC (2018) Financial appraisal of using Scheffler dish for steam based institutional. Renew Energy 30:1-12

27. Flueckiger SM, Yang Z, SV Garimella (2013) Design of moltensalt thermocline tanks for solar thermal energy storage. CTRC Research Publications, pp 1-50

28. Hosseini MRRBMJ (2015) Thermal analysis of PCM containing heat exchanger enhanced with normal annular fines. Mech Sci 6:221-234

29. Malan RDFDDJ (2015) Solar thermal energy storage in power generation using phase change material with heat pipes and fins to enhance heat transfer. Energy Procedia 69:925-936

30. Kalapala L, Devanuri JK (2018) Influence of operational and design parameters on the performance of a PCM based heat exchanger for thermal energy storage-a review. Journal of Energy Storage 20:497-519 
31. Nandwani SS (2009) Solar food processing- authors experience with cooking and drying in costa rica. In: International solar food processing conference, Germany

32. Zhao Y, Zheng H, Sun B, Li C, Wu Y (2018) Development and performance studies of a novel portable solar cooker using a curved Fresnel lens concentrator. Sol Energy 174:263-272

33. Indora S, Kandpal TC (2018) Institutional cooking with solar energy: a review. Renew Sustain Energy Rev 84:131-154

34. Herez A, Ramadan M, Khaled M (2018) Review on solar cooker systems: economic and environmental study for di erent for Lebanese scenarios. Renew Sustain Energy Rev 81:421-432

35. Aadiwal R, Hassani M, Kumar P (2017) An overview study of solar cookers. Int Res J Eng Technol 4(10):1651-1655

36. Mahavar PRRPNSPDS (2015) Evaluating the optimum load range for box-type solar cookers. Renew Energy 74:187-194

37. Schwarzer K, da Silva MEV (2008) Characterisation and design methods of solar cookers. Sol Energy 82:157-163

38. Buddhi LKSD (1997) Solar cooker with latent heat storage: design and experimental testing. Energy Convers Mgmt 38:493-498

39. Buddhi D, Sharma SD, Sharma A (2003) Thermal performance evaluation of a latent heat storage unit for late evening cooking in a solar cooker having three reflectors. Energy Convers Manag 44:809-817

40. Sharma DBRSASSD (2000) Design, development and performance evaluation of a latent heat storage unit for evening cooking in a solar cooker. Energy Convers Manag 41:1497-1508

41. Schwarzer Klemens, Vieira da Silva Maria Eugênia (2003) Solar cooking system with or without heat storage for families and institutions. Sol Energy 75(1):35-41

42. Geddam S, Dinesh GK, Sivasankar T (2015) Determination of thermal performance of a box type solar cooker. Sol Energy 113:324-331

43. Dinker A, Agarwal M, Agarwal GD (2017) Heat storage materials, geometry and applications: a review. J Energy Inst 90:1-11

44. Sharma A, Tyagi VV, Chen CR, Buddhi D (2009) Review on thermal energy storage with phase change materials and applications. Renew Sustain Energy Rev 13:318-345

45. Shukla A, Buddhi D, Sawhney RL (2009) Solar water heaters with phase change material thermal energy storage medium: a review. Renew Sustain Energy Rev 13:2119-2125

46. Dubey KK, Mishra R (2014) A review on properties of phase change material for solar thermal storage system. In: International conference of advance research and innovation, pp 133-142

47. Mahavar PRVMRPPDS (2013) Modeling and on-field testing of a Solar Rice Cooker. Energy 49:404-412

48. González-Avilés M, Urrieta OR, Ruiz I, Cerutti OM (2018) Design, manufacturing, thermal characterization of a solar cooker with compound parabolic concentrator and assessment of an integrated stove use monitoring mechanism. Energy Sustain Dev 45(135-141):2018

49. Nayak J, Agrawal M, Mishra S, Sahoo SS, Swain RK, Mishra A (2018) Combined heat loss analysis of trapezoidal shaped solar cooker. Case Studies in Thermal Engineering 12:94-103

50. Beikircher T, Reuß M, Streib G (2015) Vacuum super insulated heat storage up to $400 \mathrm{C}$. In: International renewable energy storage conference, IRES, At Düsseldorf

51. Fantucci S, Lorenzati A, Kazas G, Levchenko D, Serale G (2015) Thermal energy storage with super insulating materials: a parametrical analysis. Energy Procedia 78:441-446

52. Beikircher T, Demharter M (2013) Heat transport in evacuated perlite powders for super- insulated long term storage up to $300^{\circ} \mathrm{C}$. Heat Transfer ASME J 135:1-11
53. Sarbu I, Sebarchievici C (2018) A comprehensive review of thermal energy storage. Sustainability 10:1-32

54. Khiraiya K, Patel Dharati (2015) Performance analysis of latent heat storage unit with packed bed system- an experimental approach for discharging process. Int J Eng Res 3(4):1-7

55. Sarviya RM, Agrawal A (2016) Enhancement of thermal performance of latent heat solar storage system. World Econ Sci Eng Tech Int J Energy Power Eng 10(6):733-738

56. Cuce PM (2018) Box type solar cookers with sensible thermal energy storage medium: a. Sol Energy 166:432-440

57. Tian CZY (2013) A review of solar collectors and thermal energy storage in solar thermal. Appl Energy 104:538-553

58. Hahne E (2009) Storage of sensible heat. Energy Storage Systems Published by EOLSS Publication, oxford, UK, 2009, vol 1 , pp 1-9

59. Bauer T, Laing D, Kröner U, Tamme R (2009) Sodium nitrate for high temperature latent heat storage. In: The 11th international conference on thermal energy storage-effstock, Stockholm, Sweden

60. Moens L, Blake DM (2005) Advanced heat transfer and thermal storage fluids. In DOE Solar Energy Technologies of the U.S. Department of EnergyOffice, Denver, Colorado

61. Nkhonjera L, Bello-Ochende T, John G, Kingondu CK (2017) A review of thermal energy storage designs, heat storage materials and. Renew Sustain Energy Rev 75:157-167

62. Mussard M, Nydal OJ (2013) Charging of a heat storage coupled with a low-cost small-scale solar parabolic trough for cooking purposes. Sol Energy 95:144-154

63. Masatin V, Volkova A, Hlebnikov A, Latosov E (2017) Improvement of district heating network energy efficiency by pipe insulation renovation with PUR foam shells. Energy Procedia 11:265-269

64. Yogesh J (1998) Design and optimization of thermal systems. The McGraw-Hill Companies, INC, Singapor

65. Permatasari R, Yusuf AM (2018) Material selection for shell and tube heat exchanger using. In AIP conference, 1977

66. Solé $\mathrm{A}$, Fontanet $\mathrm{X}$, Barreneche $\mathrm{C}$, Martorell I, Fernández $\mathrm{Al}$, Cabeza LF (2012) Parameters to take into account when developing a new thermochemical energy storage system. Energy Procedia 30:380-387

67. levers S, Lin W (2009) Numerical simulation of three-dimensional flow dynamics in a hot water storage tank. Appl Energy 86:2604-2614

68. Reddy KD, Venkataramaiah P, Lokesh TR (2014) Parametric study on phase change material based thermal energy storage system. Energy Power Eng Sci Res 6:537-549

69. Srivastva U, Malhotra R, Kaushik S (2015) Recent developments in heat transfer fluids used for solar thermal energy applications. J Fund Renew Energy Appl 5(6):1-11

70. Singh SK, Chaudhari J (2016) Design and optimization of thermal storage tank using CFD. Int J Recent Innov Trends Comput Commun 4(4):126-131

71. Qiu S, White M (2013) Phase change material thermal energy storage system design and optimization. In: Proceeding of ASME 2013,7 th international conference on energy sustainability and 11 th fuel cell science, engg \& tech conference, ESfuel cell 2013, Minneapolis, MN, USA

72. Magin BWMJASDDTRL (1961) Transition temperatures of the hydrates of Na2S04, Na2HP04 and KF as fixed points in biomedical thermometry. J Res Natl Bureau Stand 86(2):181-192

73. Solé A, Neumann SNLFCEPH (2014) Thermal stability test of sugar alcohols as phase change materials for medium temperature energy storage application. Energy Procedia 48:436-439 
74. Silakhori M, Naghavi M, Metselaar H, Mahlia T, Fauzi H, Mehrali M (2013) Accelerated thermal cycling test of microencapsulated paraffin wax/polyaniline made by simple preparation method for solar thermal energy storage. Mater MDPI J 6:1608-1620

75. Sun W, Zhao Z, Wang Y (2017) Thermal analysis of a thermal energy storage unit to enhance a workshop heating system driven by industrial residual water. Energies 10:1-19

76. Xu H, Sze JY, Romagnoli A, Py X (2017) Selection of phase change material for thermal energy storage in solar air conditioning systems. Energy Procedia 105:4281-4288

77. Lecuona A, Nogueira Jl, Ventas R, Legrand M (2013) Solar cooker of the portable parabolic type incorporating heat storage based on PCM. Appl Energy 111:1136-1146

78. Gasia J, Martin M, Sole A, Barreneche C, Cabeza L (2017) Phase change material selection for thermal processes working under partial load operating conditions in the temperature range between 120 and $200^{\circ} \mathrm{C}$. Appl Sci 7:722

79. Beemkumar N, Karthikeyan A, Parthasarathy C, Bright BB (2015) Heat transfer analysis of latent heat storage system using D-Sorbitol as PCM. ARPN J Eng Appl Sci 10(11):5017-5021

80. Diarce IÁ-CA-RUG (2015) Eutectic mixtures of sugar alcohols fo rthermal energy storage. Sol Energy Mater Sol Cells 134:2115-2226

81. Bauer T, Dorte L, Ulrike K, Tamme R (2009) Sodium nitrate for high temperature latent heat storage. In: The 11th international conference on thermal energy storage-Effstock, Stockholm, Sweden

Publisher's Note Springer Nature remains neutral with regard to jurisdictional claims in published maps and institutional affiliations. 